\title{
A családi háttér és a munkaerő-piaci sikeresség összefüggései
}

\section{The Relationship between Family Background and Labor Market Success}

\author{
B. PIROHOV-TóTH ${ }^{1}$,Zs. KISS ${ }^{2}$ \\ ${ }^{1}$ Debreceni Egyetem Ihrig Károly Doktori Iskola, t.barbi599@gmail.com \\ 2Debreceni Egyetem Gazdaságtudományi Kar, Vezetés- és Szervezéstudományi Intézet, \\ kiss.zsuzsanna@econ.unideb.hu
}

Absztrakt. Tanulmányunkban arra vállalkozunk, hogy feltárjuk a diplomás (abszolutóriumot szerzett) pályakezdők társadalmi hátterét képzési területek szerint. Ennek során nagy hangsúlyt fektetünk a szülők iskolai végzettségére és a család anyagi helyzetére, hiszen e tényezők jelentős hatást gyakorolhatnak a fiatalok tanulási lehetőségére, attitüdjére, valamint szakmai pályafutására. Elemzésünk elméleti részében fontosnak tartjuk ismertetni a hazai és nemzetközi szerzők szocio-ökonómiai helyzettel kapcsolatos tapasztalatait. A feltárt szakirodalmak alapján az alábbi hipotézist állítottukfel: azon felsőfokú végzettséggel rendelkezők, akik szülei magasabb iskolai végzettséggel rendelkeznek, valamint jobb anyagi helyzetü családokból származnak, sikeresebben tudnak munkát vállalni, valamint magasabb jövedelemre tesznek szert, mint akiknek a szülei alacsonyabb iskolai végzettséggel rendelkeznek, valamint szerényebb anyagi helyzetű családokból származnak. Kutatásunk során arra a kérdésre is kerestük a választ, hogy hogyan alakul a szülők legmagasabb iskolai végzettsége, illetve anyagi helyzete a különböző tudományterületen abszolutóriumot szerzett fiatalok esetében. Hipotézisünk vizsgálatához a Diplomás Pályakövetési Rendszer (DPR) 2015-ös adatbázisa nyújtott számunkra kiváló lehetôséget, hogy a 34 felsőoktatási intézmény által gyüjtött komplex adatokat tanulmányozhassuk. Elemzésünk során rávilágítottunk a különböző tudományterületek végzettjeinek eltérő szocio-ökonómiai hátterére. Vizsgálati eredményeink alapján arra a következtetésre jutottunk, hogy a magasabb jövedelmü családokból származó fiatal diplomások elönyösebb helyzetben vannak a munkaerőpiacon, magasabb jövedelemre tesznek szert, szemben az alacsonyabb társadalmi státuszú szülők gyerekeivel.

Kulcsszavak: diplomás fiatalok, családi háttér, iskolai végzettség. anyagi helyzet, képzési területek

Abstract. In our study, we undertake to explore the social background of fresh graduates (has absolutorium) by field of science. We put great emphasis on the educational attainment of the parents and the financial situation of the family, as these factors can have a significant impact on young people's learning opportunities, attitudes and career paths. In the theoretical part of our research, we consider it important to present the 
experiences of domestic and international authors on the socio-economic situation. Based on the published literature, we proposed a hypothesis that the young graduates, whose parents have a higher education and come from better-off families, can work more successfully and earn a higher income than those whose parents are lower educated and come from financially disadvantaged families. In our research, we also looked for the answer to the question of how the parents' highest educational attainment and financial situation develop in the case of young people who have graduated in different fields of science. Subsequently, the 2015 Graduate Career Tracking System (DPR) database provided us an excellent opportunity to study the complex data collected by the 34 higher education institutions. In our analysis, we highlighted the different socio-economic backgrounds effect on career of graduates from different disciplines. Based on our research, we have concluded that young people from richer families are in a better position on the labor market, earning higher incomes than children of parents with lower social status.

Keywords: fresh graduates, family backgrounds, educational attainment, financial situation, field of study

\section{Bevezetés}

A kutatás a diplomával (abszolutóriummal) rendelkező fiatalok szocio-demográfia helyzetét igyekszik feltárni képzési területek szerint. Ennek során külön figyelmet fordítunk a szülők iskolai végzettségére és a család anyagi helyzetére vonatkozóan. A Diplomás Pályakövetési Rendszer (DPR) 2015-ös adatbázisa kiváló lehetőséget nyújtott számunkra, hogy a 34 felsőoktatási intézmény által gyűjtött komplex adatokat tanulmányozhassuk. Vizsgálatunkban arra a kérdésre keressük a választ, hogy milyen szerepe van a családi háttérnek a felsőfokú végzettséggel rendelkező munkavállalók munkaerő-piaci sikerességét tekintve.

Az oktatásszociológiai szakirodalomban számos szerző [3,5,13,19] esszenciális jelentőséget tulajdonít a szocio-ökonómiai státusz szerepének. Megállapították, hogy a gyermek iskolai teljesítményét, későbbi tanulási törekvéseit a család financiális helyzete nagymértékben befolyásolja. Ezt a tényt erősíti meg Coleman [6] is 1996-ban keletkezett múvében, melyben rámutat arra, hogy a családi háttér három összetevőjének egyike a család jövedelmi-, vagyoni helyzetét magába foglaló pénzügyi tőke, mely oly módon segíti a teljesítményt, hogy forrást biztosít olyan eszközök és szolgáltatások megvásárlásához, melyek segítségével a gyerekek jobb iskolai teljesítményt érhetnek el. Amennyiben a pénzügyi tőke hiányos, úgy az akár a gyermek iskolai teljesítményének rovására mehet. Vincze [23] rávilágít arra, hogy a fiatalok munkavállalással kapcsolatos döntéseit és ennek kapcsán az álláskeresési idejét és a rezervációs bérüket, szabadidő-preferenciájukat is lényegesen meghatározza a családjuk gazdasági erőforrása. Továbbá a család nem megfelelő anyagi helyzete esélyegyenlőtlenséget szülhet gyermekük oktatási rendszeren történő áthaladása során. 
Számos hazai kutatás [9,11,15,17,21] eredményei igazolják, hogy a differens kulturális mutatókkal rendelkező közösségekből származó fiatalok eltérő arányban jelentkeznek a felsőoktatásba, specifikusan rendeződnek el a különböző tekintélyű intézmények között, sőt az alacsony státusú szülők gyermekei előtt egyes intézmények vagy szakok valósággal lezárulnak. Boudon [4] szemlélete szerint az alsóbb osztályba tartozó emberek nem egy általuk egyértelműen befolyásolható dologként tekintenek a sikerre, sőt főleg a siker anyagi természetű felfogása él bennük, ezért valószínűsíti, hogy az alacsonyabb jövedelemmel rendelkező családok kevésbé érzik magukat érdekeltnek a továbbtanulásban. A szerző a költség-haszon-kalkulációhipotézisében hangsúlyozza, hogy a társadalom alacsonyabb szintjén elhelyezkedők hajlamosabbak alábecsülni azokat a gazdasági és társadalmi előnyöket, amelyek a magasabb képzettség megszerzéséből származnának, sőt a jövőbeli előnyök helyett a jelenbelieket helyezik előtérbe. Pierog és szerzőtársai [12] tanulmányukban szintén felhívják a figyelmet azokra a hátrányos helyzetű csoportokra (pl. pályakezdők, szakképzetlenek), akik a munkaerőpiacon való elhelyezkedésük során nehézségekbe ütközhetnek. Barizsné és Polónyi [2] a hazai felnőttoktatás jellemzőinek feltárása során három csoportra bontották a résztvevők körét: hátrányos helyzetű csoportok, foglalkoztatottak csoportja és az inaktívak csoportjai. Az általunk tárgyalt családi háttér változó a szerzők kategóriáit tekintve a hátrányos helyzethez köthető. Tanulmányukban bemutatják, hogy milyen okai, ismérvei lehetnek e hátrányos helyzetnek, s hogy felnőttképzési programok tekintetében milyen eszközökkel segíthetők életútjuk során. Szintén a hátrányos megkülönböztetés egyik okaként említi Dajnoki és Balázs-Földi [7] kutatásában a családi körülményeket. A szülői minta ugyanis szoros összefüggésben áll a továbbtanulási irányokkal, ezzel pedig erőteljes hatást gyakorol a gyermek szakmai pályafutására, valamint tanulási attitűdjeire. A felsőfokú végzettséggel rendelkező szülő jelenléte a családban az esetek nagy részében magasabb szintű végzettség megszerzésére ösztönzi az utódokat is, hiszen egyfajta mintaadóként szolgál számukra. A mesterképzés elvégzését követően a frissen végzettek várhatóan magasabb bérelőnyre tehetnek szert a munkaerőpiacon, mint az alapképzettséggel rendelkező társaik [11]. Kiss [10] korábbi elemzésében felhívja a figyelmet arra, hogy a hasonló végzettséggel rendelkező családtag jelenléte a fiatalok első álláskeresési idejét is pozitívan befolyásolhatja. Megfigyelhető, hogy azokban a családokban, ahol a tanulás, mint érték jelenik meg, a szülők ez irányú patronálása sokkal jelentősebb eredményeket mutat, ezzel egyidejűleg pedig a gyermekeik tanulás iránti elköteleződése is tovább növekszik, így a lehető legtöbbet tesznek meg a sikeres továbbtanulásuk érdekében és feltehetően magasabb végzettségi szintet érnek el. Míg a kedvezőtlen szociális helyzetű családokban felnövő gyermekek a támogató környezet hiányában vélhetően kisebb valószínűséggel döntenek a továbbtanulás mellett. Szondi [18] tanulmányában, a mintába kerülő, munkavállalás előtt álló végzős egyetemi hallgatók ( $n=294)$ több mint fele megfelelő családi anyagi helyzettel rendelkezik, ami alátámaszthatja a 
külföldi munkavégzés iránti nagymértékű érdeklődést is a későbbi karriertervezésben. Gergely és Nagy [8] az egyetemi hallgatók körében végzett tanulási motivációt feltáró kutatása azonban arra világított rá, hogy a családi kapcsolatok kevésbé játszanak fontos szerepet a fiatalok tanulási törekvéseiben és kevésbé befolyásolják a jövőbeli munkavégzésük sikerességét.

\section{Adatok és módszer}

A vizsgálat lebonyolításához a hazai Diplomás Pályakövetési Rendszer (DPR) 2015-ös adatbázisát használtuk, melyben 34 felsőoktatási intézmény által gyüjtött komplex adatokat tanulmányozhattunk a végzett hallgatókra vonatkozóan. A felsőoktatási intézmények által végzett online kérdőíves megkérdezés a 2010-ben, 2012-ben és 2014-ben diplomázott fiatalokra terjedt ki, akik hagyományos egyetemi, főiskolai, egységes és osztatlan, illetve alap és mesterképzésen végeztek. Az adatfelvételek révén összeállt adatbázis elemszáma 20579 fó, így az átlagos válaszadási ráta 12\% [22]. Tanulmányunkban a fent említett korábbi elemzés (DPR 2015) adatai segítségével statisztikai elemzéseket végeztünk. Az abszolutóriumot szerzett hallgatók szociodemográfia helyzetét vizsgálva elsőként a szülők iskolai végzettségét mértük fel, majd ezt tovább bontottuk $^{1}$ a különböző képzési területeken végzett hallgatók csoportjaira. Feltártuk, hogy milyen arányban diplomás, értelmiségi szülők gyermekei, vagy milyen arányban jöttek nem diplomás családi háttérből, tehát ún. első generációs értelmiségiek. Ez kiegészítésre került annak vizsgálatával is, hogy az egyes képzési területek képviselői milyen anyagi helyzetben éltek 14 éves korukban. Továbbá független kétmintás t-próbák segítségével megvizsgáltuk, hogy a megkérdezettek keresete hogyan viszonyul szüleik anyagi helyzetéhez. Kétértékű változókat alakítottunk ki, ahol az átlagosnál gazdagabbnak tekintjük azokat, akik esetében az átlagosnál valamivel, vagy sokkal jobb volt a család anyagi helyzete 14 éves korban, illetve az átlagosnál szegényebbnek tekintjük azokat, akik esetében az átlagosnál valamivel, vagy sokkal rosszabb volt a család anyagi helyzete 14 éves korban. A család anyagi helyzetét átlagosnak jelölőket a vizsgálat során kihagytuk, ami adatvesztéssel járt ugyan, de pontosabb elemzést tett lehetővé, hiszen célunk az volt, hogy a jobb vagy rosszabb anyagi helyzetben lévő családokból származók közötti különbségeket összevessük.

\section{Empirikus eredmények}

A Monitor 1997-es felmérése [20], valamint a TIMSS [16] 2015-ös vizsgálata egyaránt igazolta Magyarországon a családi háttértényezők teljesítményre gyakorolt kiemelkedő hatását. Elemzésünkben a korábbi vizsgálatok eredményeinek felülvizsgálatára vállalkoztunk, melyben

\footnotetext{
1 Elemzésünk során a következő változókat vontuk be: A szülők legmagasabb iskolai végzettsége: $1=$ legfeljebb 8 általános, $2=$ szakmunkásképző, szakiskola érettségi nélkül, 3 = szakiskola, technikum, 4 = gimnázium, $5=$ főiskola, $6=$ egyetem, tudományos fokozat
} 
95\%-os konfidencia intervallumok mutatják a minta átlagától való jelentős eltérést képzési területek szerinti bontásban.

\subsection{A szülők legmagasabb iskolai végzettségének lehetséges összefüggései}

Az alábbi diagram [1. ábra] a megkérdezett fiatalok szüleinek legmagasabb iskolai végzettsége szerinti megoszlását mutatja. A teljes mintát figyelembe véve a legfeljebb 8 általánost végzett szülők gyakorisága a legalacsonyabb a mintában. Ha csak a diplomás szülők arányát vizsgáljuk, akkor a 2015-ös adatfelvétel válaszolói körében a frissdiplomások apjának 34,1\%-a, anyjának 38,3\%-a diplomás, azaz főiskolai vagy egyetemi végzettségű (beleértve a tudományos fokozattal rendelkezőket is). A vizsgált populációban az anyák esetében magasabb a diplomások aránya.

1. ábra: A szülők legmagasabb iskolai végzettsége Forrás: saját szerkesztés a DPR (2015) adatai alapján

Az 2. ábra szemlélteti az édesapák iskolai végzettségét képzési területek szerinti (95\%-os konfidencia intervallumok), míg a 3. ábra az édesanyákét. Első körben külön-külön vizsgálat alá

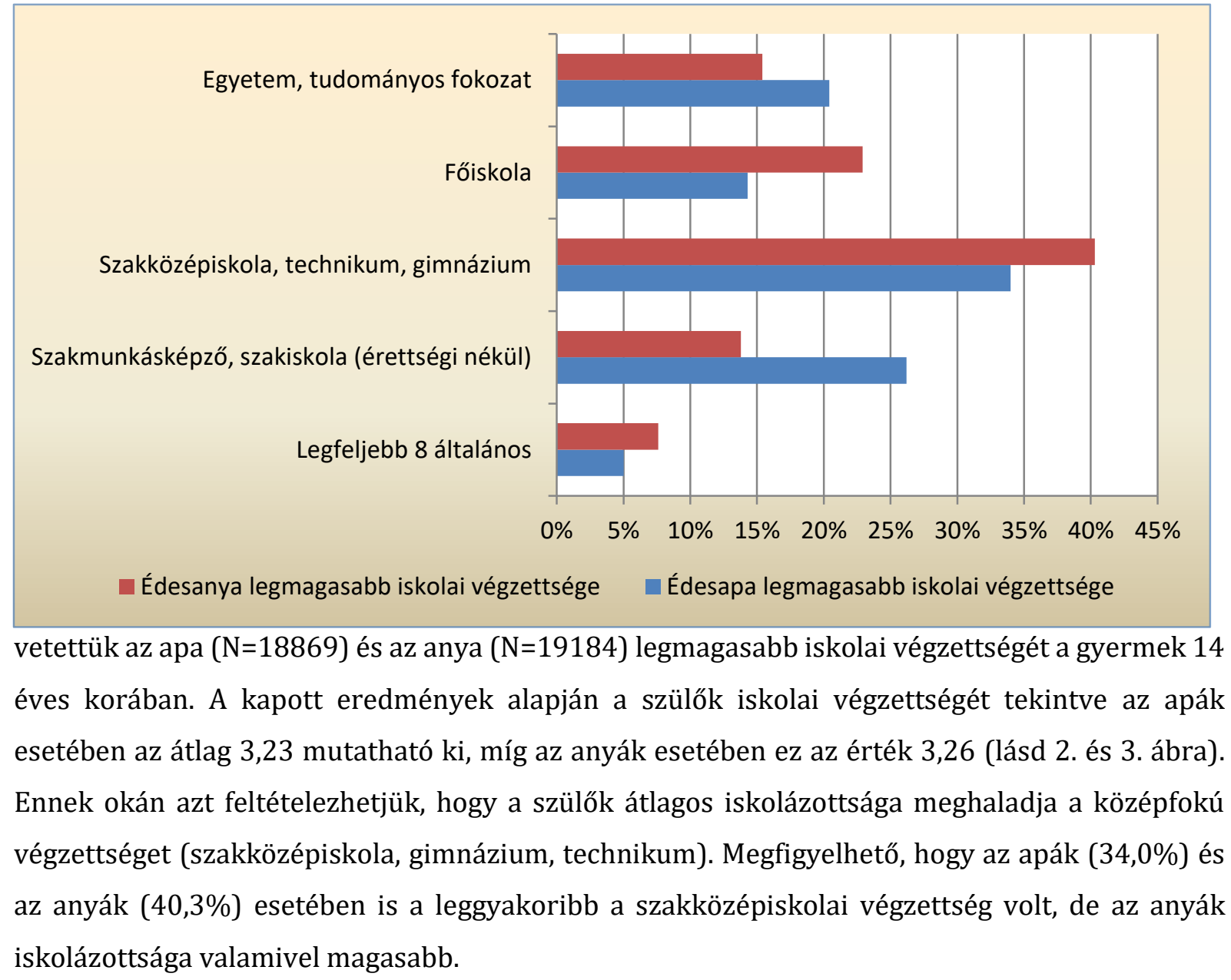




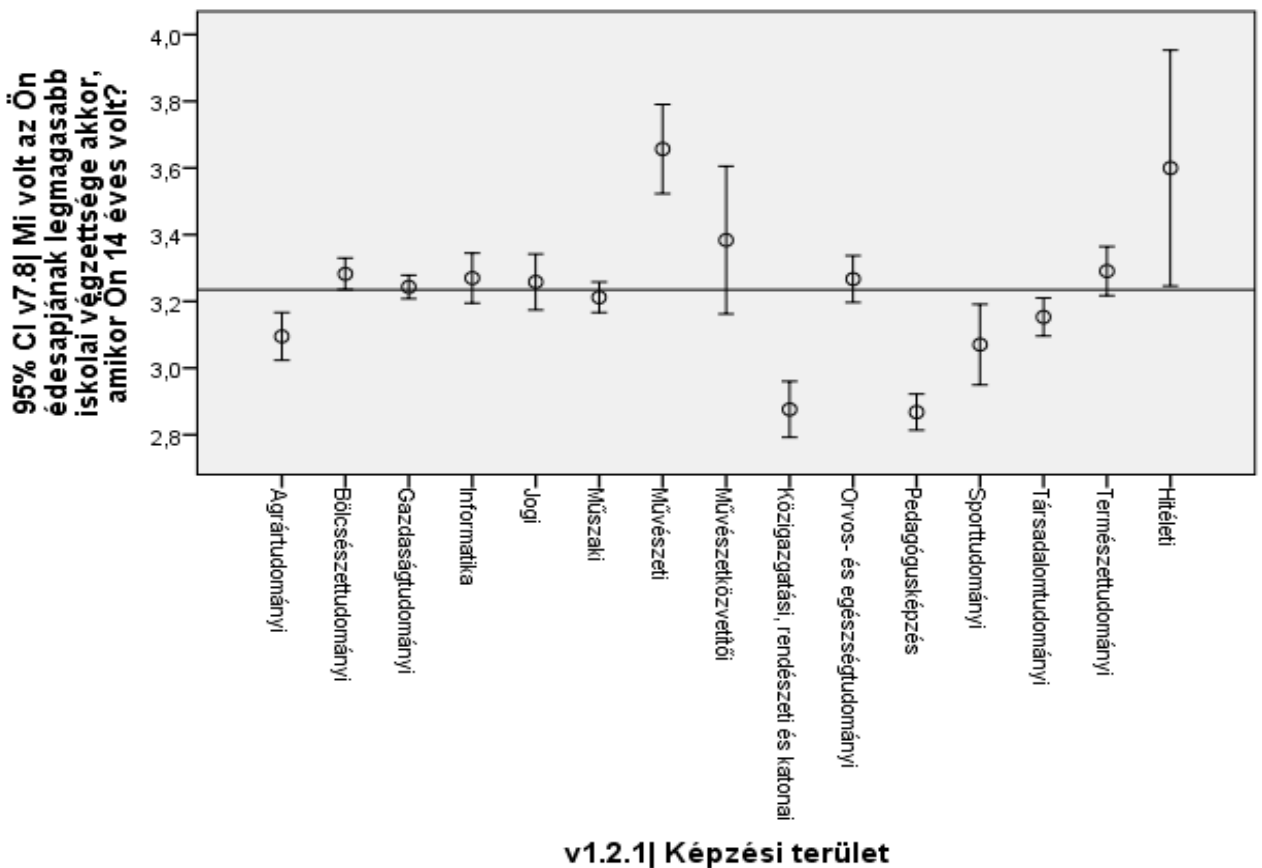

2. ábra: Az édesapák legmagasabb iskolai végzettsége képzési területek szerint Adatok forrása: DPR 2015

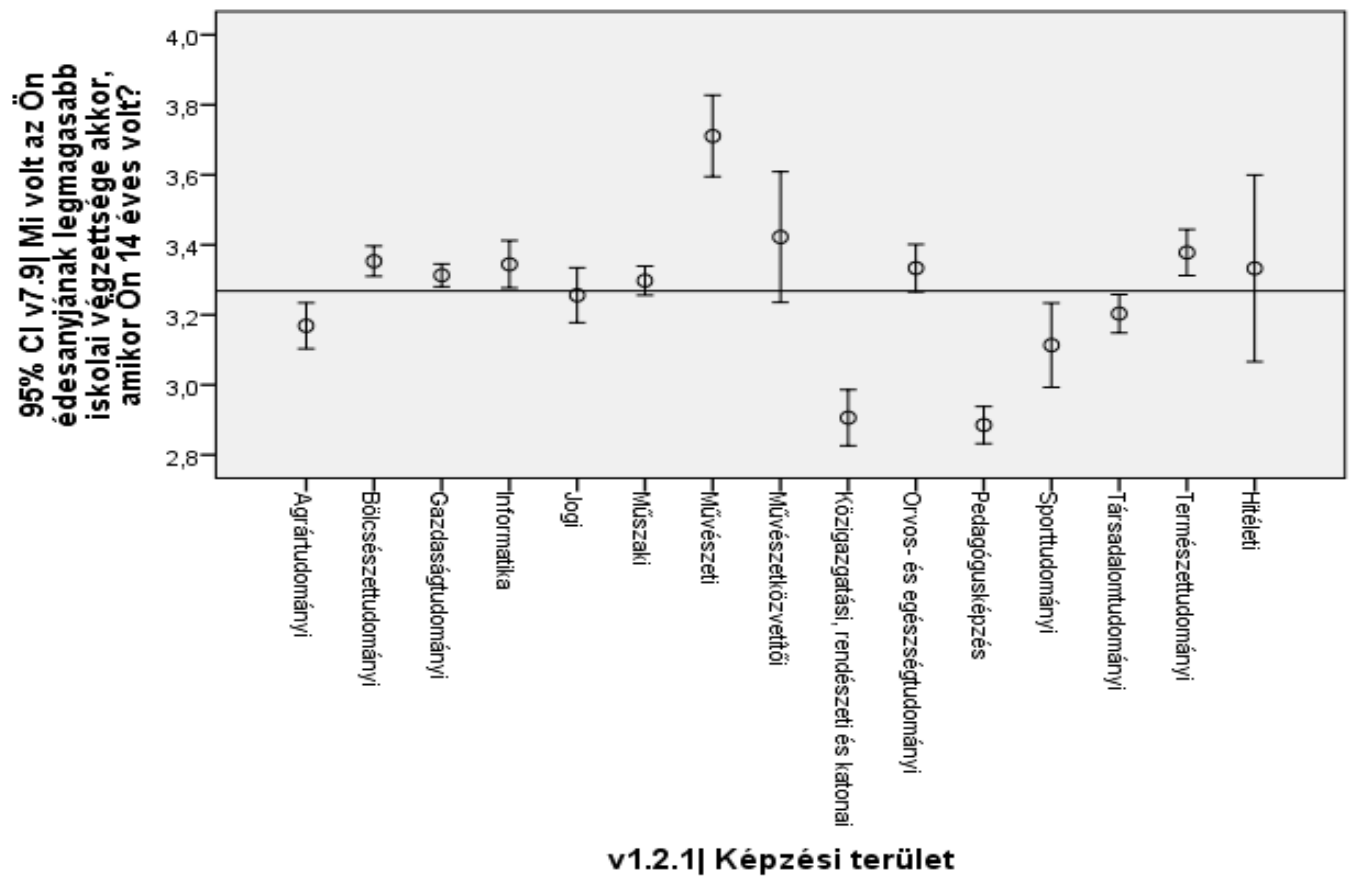

3. ábra: Az édesanyák legmagasabb iskolai végzettsége képzési területek szerint Adatok forrása: DPR 2015

A képzési területek alapján folytatott vizsgálatunkkal rámutattunk arra, hogy a szülők legmagasabb iskolai végzettsége a művészeti és hitéleti képzési területeken végzettek esetében mutatkozik meg (lásd 2. és 3. ábra). A pedagógiai és közigazgatási tudományterületen 
abszolutóriumot szerzettek esetében a szülők iskolai végzettsége az átlagostól alacsonyabb (lásd a 95\%-os konfidencia intervallumokat). Ez összefügghet azzal a jelenséggel is, hogy azok, akiknek a családjában nincs diplomás - azaz „nem tradicionális hallgatók” - azokra a területekre, szakokra aspirálnak, ahova a bejutás könnyebb, így sajátos „non-traditional” felsőoktatási életutak alakulnak ki $[9,14]$.

\subsection{A család anyagi helyzete a kérdezettek 14 éves korában képzési területenként}

A teljes mintát $(\mathrm{N}=19186)$ figyelembe véve kijelenthető, hogy a frissen végzett diplomások családjának 14 éves korukban mért anyagi helyzete összességében egy picivel az átlag $(0,076)$ fölött van² . A magasabb társadalmi színvonalon élő családok aránya (30,8\%) magasabb, mint az átlag alatt élő családoké $(22,8 \%)$. A 4. ábrán szembetűnő, hogy a család anyagi helyzetének megítélése a képzési területek szerint is jelentős különbségeket mutat. Vizsgálatunk során megállapítást nyert, hogy a család financiális helyzetét jellemző változó átlaga a jogász, a gazdaságtudományi és a múvészeti, társadalomtudományi végzettségű fiatalok esetében a legmagasabb. A közigazgatási, pedagógusi és sporttudományi, természettudományi szakon végzett hallgatókat pedig alacsonyabb jövedelmű családból származónak tekinthetjük.

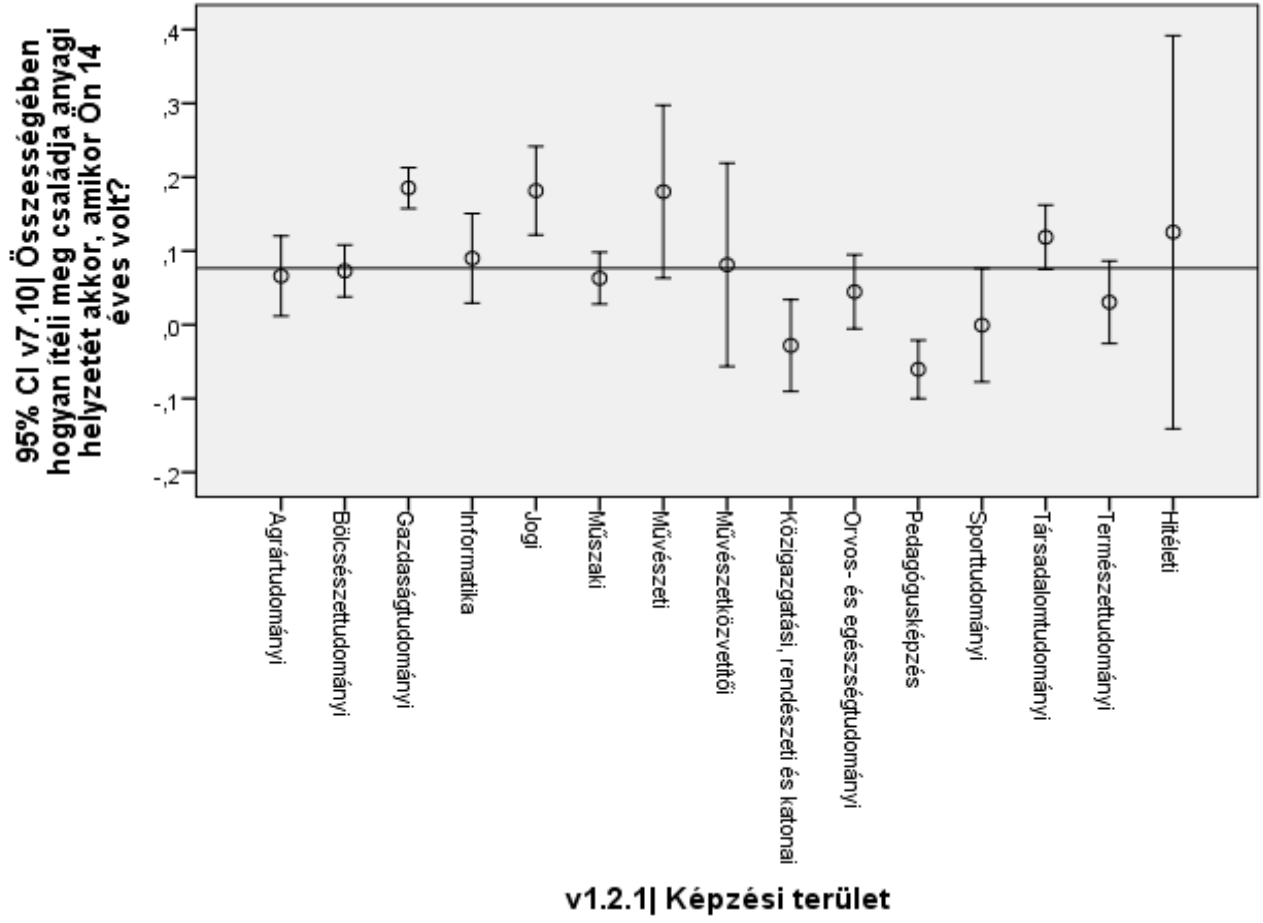

\footnotetext{
${ }^{2}$ A család anyagi helyzete az ön 14 éves korában:-2 = az átlagosnál sokkal rosszabb, -1 = az átlagosnál valamivel rosszabb, $0=$ kb átlagos, 1 = az átlagosnál valamivel jobb, 2 = az átlagosnál sokkal jobb
} 


\section{4. ábra: A család anyagi helyzete képzési területek szerint} Forrás: DPR 2015

\subsection{A diplomások jelenlegi keresete a családi háttér tükrében}

Megvizsgáltuk a frissdiplomások keresete és a család anyagi helyzete közötti kapcsolatot. Összevetettük az átlagosnál gazdagabb és szegényebb családokból származók keresetét. A fiatal diplomások utolsó havi fizetése a DPR általunk vizsgált adatbázisa alapján a szegényebb családból (N=3419) származók esetében átlagosan 205 ezer forint, szórása 133 ezer forint. A gazdagabb családból (N=4440) származók esetében ez számottevően magasabb, átlagosan 222 ezer forint, melynek szórása 147 ezer forint. A várható értékek egyezőségét független kétmintás $t$-próba segítségével ellenőriztük (1. táblázat). Különbözőnek tételezhetjük fel a két vizsgált csoport varianciáját ( $F=23,157$; szig. $<0,001)$. Az elvégzett Welch-próba eredménye alapján $(t=-5,156$; szabadságfok = 7655,51; szig.< 0,001) arra következtethetünk, hogy a gazdagabb családokból származók a munkaerőpiacon magasabb saját keresettel rendelkeznek, tehát a gazdagabb és szegényebb családból származók keresetének különbsége statisztikailag is szignifikáns. Hasonló eredményre jutott Andor és Liskó [1] 2000-ben elvégzett kutatásukban, eredményeik szerint a magasabb társadalmi státuszú családok gyerekei generáción keresztül öröklődnek, mindig magasabb iskolai végzettséget szereznek, jobb munkakörben tudnak elhelyezkedni, ezáltal pedig magasabb jövedelemre tesznek szert, szemben az alacsonyabb társadalmi státuszú, alacsony iskolai végzettségű szülők gyerekeivel.

\begin{tabular}{|c|c|c|c|c|c|c|}
\hline \multicolumn{2}{|c|}{} & \multicolumn{5}{|c|}{ t-próba az átlagok egyenlőségére } \\
\cline { 3 - 7 } & & $\mathrm{F}$ & Szig. & $\mathrm{t}$ & $\mathrm{df}$ & Szig. \\
\hline $\begin{array}{c}\text { Mennyi volt az előző } \\
\text { hónapban a főállásából } \\
\begin{array}{c}\text { származó havi nettó keresete? } \\
\text { (nettó ezer ft/hónap) }\end{array}\end{array}$ & $\begin{array}{c}\text { Egyenlő } \\
\text { variancia }\end{array}$ & 23,157 & 0,001 & $-5,156$ & 7655,51 & 0,001 \\
\hline
\end{tabular}

1. táblázat: A diplomások utolsó havi bére

Forrás: szerkesztett ábra a DPR (2015) adatai alapján

\section{Következtetések}

Tanulmányunkban az abszolutóriummal rendelkező fiatalok szocio-ökonómia státuszát (szülők legmagasabb iskolai végzettsége és a család anyagi helyzete) elemeztük képzési területek szerint. Továbbá független kétmintás t-próba segítségével megvizsgáltuk, hogy a család financiális körülményei hogyan befolyásolhatják a felsőfokú végzettséggel rendelkezők jövedelmét. A vizsgált kérdéseket a Diplomás Pályakövető rendszer (2015) adatbázisán teszteltük. Eredményeink jórészt megerősítették a korábbi empirikus vizsgálatok tapasztalatait (Monitor 
1997, TIMSS 2015), melyek szerint a szülők mintaadó szerepe kiemelkedő jelentőségű a fiatalok számára. Kutatási kérdésünk vizsgálata során megállapításra került, hogy magasabb iskolai végzettséggel a művészeti és hitéleti képzési területeken tanulók szülei rendelkeznek, jobb anyagi helyzetű családokból pedig a jogász, a gazdaságtudományi és a művészeti, társadalomtudományi végzettségű fiatalok származnak. Kimutatható továbbá az is, hogy a jobb financiális helyzetű családokban élő fiatalok keresete magasabb. Összevetve az eredményeket, hipotézisünk alátámasztásra került, mely szerint a magasabb iskolázottságú és magasabb jövedelmi helyzetű családból származók esetében a legerősebb a motiváció arra, hogy a gyerekek maguk is felsőoktatásba jelentkezzenek, abszolutóriumot, diplomát szerezzenek, ezáltal jövőbeni munkavégzésük során magasabb jövedelemre tegyenek szert.

\section{Hivatkozások}

[1] Andor M., Liskó I. (2000) Iskolaválasztás és mobilitás. Iskolakultúra, Budapest.

[2] Barizsné Hadházi, E., Polónyi, I. (2003) A hazai felnőttképzés jellemzői. COMPETITIO 2 (1), 36-55.

[3] Boudon, R. (1974) Education, Opportunity and Social Inequality: Changing Prospects in Western Society. New York: Wiley-Interscience.

[4] Boudon, R. (1981) The Logic of Social Action. London-Boston-Henley.

[5] Bourdieu, P. (1973) Cultural reproduction and social reproduction. In: Brown, R. K. (Ed.): Knowledge, education and cultural change. London: Tavistock.

[6] Coleman, J. S. (1996) A társadalmi tőke. In. Lengyel, Gy., Szántó, Z. (szerk). A gazdasági élet szociológiája. BKE Szociológiai és Szociálpolitikai Tanszék, Budapest, 99-129.

[7] Dajnoki K., Balázs-Földi E. (2016) Diszkrimináció a munkaeröpiacon. Közép-Európai Közlemények, 9 (3),150-165.

[8] Gergely É., Nagy R. (2015) Gazdasági szakos hallgatók tanulási motivációjának és személyes kompetenciáinak vizsgálata. Közép Európai Közlemények. 8(4), 197-205.

[9] Kiss L. (2013) „Alacsony státuszú” szakok az alapképzésben. In: Garai, O. - Veroszta, Zs. (szerk.): Frissdiplomások 2011. Budapest, Educatio Társadalmi Szolgáltató Nonprofit Kft. 67-91.

[10] Kiss Zs. (2015) Fiatal magyar diplomások foglalkoztathatósága: Az első álláskeresési időt befolyásoló tényezők. In Pusztai Gabriella, Kovács Klára: Ki eredményes a felsőoktatásban? Nagyvárad, Partium Press, pp. 55-65.

[11] Kun A. I. (2016) Az intézményi hatás megjelenése a kereseti különbségekben. In: Pusztai, Gabriella; Bocsi, Veronika; Ceglédi, Tímea (szerk.) A felsőoktatás (hozzáadott) értéke, Partium; Új Mandátum; PPS (2016) pp. 165-176. 
[12] Pierog A., Dajnoki K., Vörös P. (2015) Civil szervezetek szerepe a foglalkoztatásban és képzésben- Egy sikeres debreceni együttmúködés. Acta Scientiarum Socialium Universitas Kaposváriensis, Studia Scientiarum Socialium, Vol.43, pp. 47-56

[13] Pusztai G. (2004) Iskola és közösség. Budapest: Gondolat.

[14] Pusztai G. (2015) Pathways to success in higher education: Rethinking the Social Capital Theory in the Light of Institutional Diversity. Frankfurt am Main: Peter Lang Verlag.

[15] Róbert P. (2000): Bővülő felsőoktatás - ki jut be? Educatio. 9 (1). 79-94.

[16] Szalay B., Szepesi I., Vadász Cs. (2016) TIMSS 2015 Összefoglaló jelentés. Okt. Hiv., Budapesthttps://www.oktatas.hu/pub_bin/dload/kozoktatas/nemzetkozi_meresek/timss /TIMSS2015.pd

[17] Szemerszki M. (2012) A felsőfokú képzésbe belépők társadalmi háttere, iskolai életútja, a középfokú oktatás föbb sajátosságai. In: Szemerszki M. (Szerk.): Az érettségitől a mesterképzésig. Továbbtanulás és szelekció. Budapest: Oktatáskutató és Fejlesztő Intézet. 113-140.

[18] Szondi R. (2019) Egyetemisták külföldi munkavállalással kapcsolatos attitüdje. Taylor: Gazdálkodás- és Szervezéstudományi Folyóirat: A Virtuális Intézet Közép-Európa Kutatására Közleményei. (2) pp. 92-100. https://ojs.bibl.u-szeged.hu/index.php/taylor/article/view/31780/31556

[19] Tinto, V. (1993) Leaving college. Rethinking the Causes ad Cures of Student Attrition. ChicagoLondon: The University of Chicago Press.

[20] Vári P. (1999) Monitor 97’. A tanulók tudásának változása. Országos Közoktatási Intézet, Budapest.

[21] Veroszta Zs. (2012) A felsőoktatás különböző szintjeire felvettek jellemzői. In: Szemerszki, M. (Szerk.): Az érettségitől a mesterképzésig. Továbbtanulás és szelekció. Budapest: Oktatáskutató és Fejlesztő Intézet. 51-82.

[22] Veroszta Zs. (2016) Frissdiplomások 2015. Kutatási zárótanulmány. Diplomás Pályakövetési Rendszer Országos Kutatás. Oktatási Hivatal Felsőoktatási Elemzési Főosztály.

[23] Vincze Sz. (2013) A felsőoktatás és a munkaerőpiac inkongruenciája. Eötvös Kiadó, Budapest 